\title{
PHOTOMETRIC DETECTION OF AMINO ACID SARCOSINE USING ITS HYDROLYSIS BY SARCOSINE OXIDASE AND AMPLEX RED FLUOROPHORE
}

\author{
${ }^{1}$ Martina STANKOVA, ${ }^{1}$ Michaela VSETICKOVA, 'Zuzana TOTHOVA, ${ }^{1}$ Dagmar UHLIROVA, \\ ${ }^{2}$ Branislav RUTTKAY-NEDECKY, ${ }^{3}$ Marta KEPINSKA, ${ }^{1} \mathrm{~J}$ osef RUZICKA, ${ }^{3}$ Halina MILNEROWICZ, \\ ${ }^{4}$ Warawan EIAMPHUNGPORN, ${ }^{1,2,3}$ Rene KIZEK \\ ${ }^{1}$ Department of Research and Development, Prevention Medicals s.r.o., Studenka-Butovice, \\ Czech Republic, EU stankova@preventionmedicals.cz \\ ${ }^{2}$ Department of Human Pharmacology and Toxicology, University of Veterinary and Pharmaceutical \\ Sciences Brno, Czech Republic, EU, kizek@sci.muni.cz \\ ${ }^{3}$ Department of Biomedical and Environmental Analyses, Faculty of Pharmacy with Division of Laboratory \\ Diagnostics, Wroclaw Medical University, Wroclaw, Poland, EU, zalewska.m@gmail.com \\ ${ }^{4}$ Department of Clinical Microbiology and Applied Technology, Faculty of Medical Technology, Mahidol \\ University, Salaya, Nakhon Pathom, Thailand, warawan.eia@mahidol.ac.th
}

https://doi.org/10.37904/nanocon.2019.8596

\begin{abstract}
Prostate cancer is the most common malignant tumor in men, whose incidence is significantly different geographically and increases with age. For rapid diagnostics, new tumor markers with higher prognostic relevance are still being sought. A very promising candidate molecule is the amino acid sarcosine. The aim of this work was to design a highly sensitive photometric detection system for the sarcosine determination. An original methodology for determining the amino acid sarcosine using Trinder's reaction with sarcosine oxidase and Amplex Red fluorophore has been proposed. To improve the enzymatic reaction sarcosine oxidase and horseradish peroxidase were immobilised on superparamagnetic irone oxide nanoparticles (SPIONs). Absorbance dependence on sarcosine concentration read off at the wavelength of $572 \mathrm{~nm}$ was linear over a total range of $0-1000 \mu \mathrm{M}(r \geq 0.99)$ with limit of detection (LOD) of $2 \mu \mathrm{M}$ and limit of quantification (LOQ) of 6 $\mu \mathrm{M}$. The suggested procedure allows to analyze the content of sarcosine in real urine specimens. The proposed method is capable of detecting sarcosine at micromolar concentrations.
\end{abstract}

Keywords: Sarcosine; prostate cancer; photometric detection; red amplex; sarcosine oxidase

\section{INTRODUCTION}

The issue of the incidence of prostate cancer in men has long been a serious health problem [1,2]. In recent years, an increase in the incidence of prostate cancer has been observed, especially in developed countries. According to WHO statistics are diagnosed each year worldwide more than 1.1 million new cases and registered about 300,000 dead men. Suitable tumor markers are sought for rapid diagnostics [3,4]. A very promising potential marker is the amino acid sarcosine ( $\mathrm{N}$-methylglycine) $[5,6]$. Sarcosine is an amino acid that is part of the metabolic pathways of glycine, serine and threonine [7]. Enzymatic methods are very suitable for automated determination of creatinine, uric acid, triacylglycerol, cholesterol, glucose or other analytes using Trinder reactions. This reaction is based on the use of a suitable dye (such as 4-aminoantipyrine, 3,3',5,5'tetramethylbenzidine and other suitable molecules) in the presence of hydrogen peroxide and peroxidase. An enzymatic-coupled colorimetric assay has been developed to quantify urinary sarcosine [8]. A number of analytical techniques are used to detect sarcosine: photometry, electrochemistry, mass detection and liquid 
chromatography [6,9]. Reaction solutions (including nanoparticles) for the determination of sarcosine by the enzymatic method for use in conventional photometers or in fully automated systems have been described [10-14]. Zinc has been shown to have a significant effect on sarcosine oxidases [15], it is therefore appropriate to use it in assays, and reaction solutions containing this enzyme. Furthermore, enzymatic methods have been proposed on various carriers (gold magnetic nanoparticles), which are useful for quantitative and qualitative analysis of sarcosine in a biological sample. The proposed method is a specific reaction based on the formation of hydrogen peroxide $\left(\mathrm{H}_{2} \mathrm{O}_{2}\right)$ by sarcosine oxidase (SOX). The released $\mathrm{H}_{2} \mathrm{O}_{2}$ reacts with Amplex Red in the presence of horseradish peroxidase (HRP) to form a red-fluorescent oxidation product, resorufin, which can be measured spectrophotometrically (OD570). Reaction conditions such as $\mathrm{pH}$ and reaction time have been optimized. Amplex Red is a highly sensitive and stable $\mathrm{H}_{2} \mathrm{O}_{2}$ probe, a great fluorogenic substrate for peroxidase [16]. In the presence of horseradish peroxidase (HRP), Amplex Red reacts in stoichiometry $1: 1$ with $\mathrm{H}_{2} \mathrm{O}_{2}$ to form a highly fluorescent resorufin $[8,17]$.

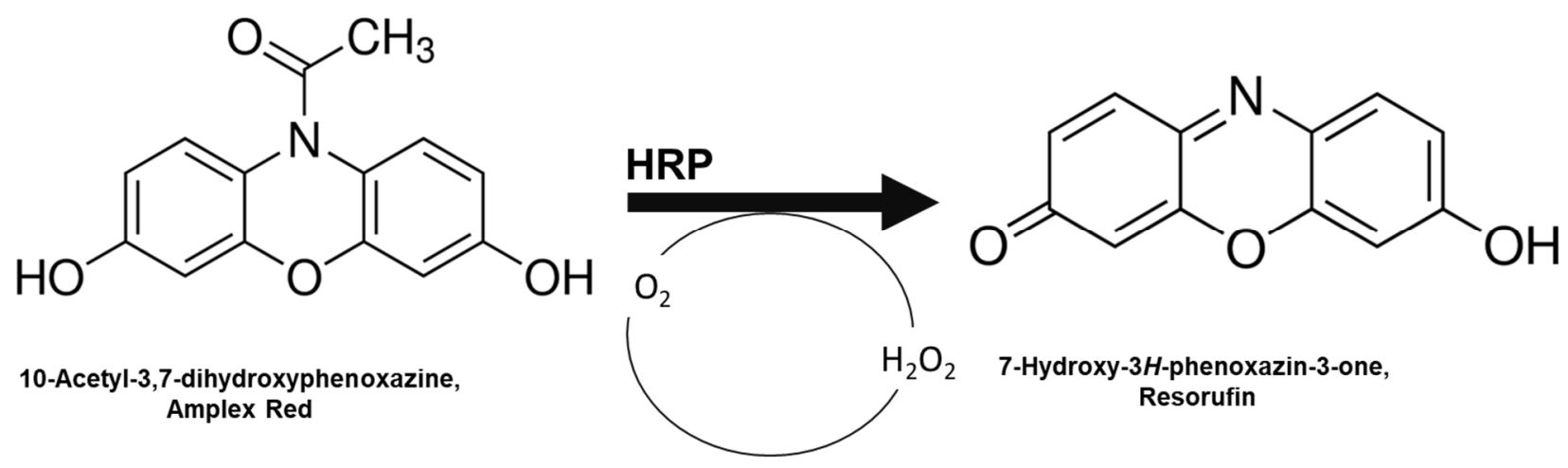

Figure 1 Schematic representation of Amplex Red conversion into Resorufin Horseradish peroxidase (HPR) enzyme uses hydrogen peroxide as an oxidizing agent to convert Amplex Red into the fluorescent Resorufin

\section{MATERIAL AND METHODS}

Chemicals: sodium citrate dihydrate, hydrogen tetrachloroaurate(III) tetrahydrate, hydrogen peroxide, sodium carbonate anhydrous, sodium hydrogen carbonate, disodium hydrogen phosphate, sodium dihydrogenphosphate, acetic acid ( $\mathrm{HAc}$ ), and sodium acetate $(\mathrm{NaAc})$ were all purchased from Merck (Germany). Amplex Red was purchased from Thermo Scientific (UK). All reagents were of analytical grade and used without any further purification. Ninhydrin, hydrindatin were purchased from Ingos (Czech Republic). Aqueous solutions for size analysis were prepared using Ultra (Elga, UK) resistivity $18 \mathrm{M} \Omega-\mathrm{cm}$. For other purposes deionized water was used. Modification of SPION with SOX: The method was described in the work of Uhlirova at al. [18]. Shortly: SPIONs/Au/NPs (40 mg) were washed 3 times with $1000 \mu \mathrm{L}$ of $1 \times P B S(p H ~ 7.0)$, $120 \mathrm{rpm}$ for 60 seconds, and then separated using a neodymium magnet. Subsequently, SPIONs/Au/NPs were dispersed using ultrasonic (USC-T, VWR Germany) $40 \mathrm{~W}$ for $10 \mathrm{~min}$. The prepared NPs were then modified with acetic acid and chitosan $(8 \mathrm{mg} / \mathrm{mL})$ and $100 \mu \mathrm{L}$ of SOX. Incubation of the NPs took place for 30 minutes on a rotator (Multi-Rotator RS 60, Biosan, Lithuania). Absorbance scan was carried out in the range from $300-850 \mathrm{~nm}$ by $2 \mathrm{~nm}$ steps, intervals between measuring were every 5 minutes. Data was evaluated at $572 \mathrm{~nm}$. All measurements were performed at $25{ }^{\circ} \mathrm{C}$ (V UV-3100PC, VWR, Germany), cuvette Brand (Germany). Blanc was measured (only reaction solution). Samples of mixed urea was pipetted to cuvette with reaction solution and add addition of sarcosine. The samples for measurements (100 $\mu \mathrm{L})$ were placed in 96 well polystyrene plate (Gamma, Czech Republic). The absorbance or spectra in plate were recorded by using a reader Varioskan Lux (Thermo Scientific, UK). Absorbance scan was measure in the range from $450-600$ 
$\mathrm{nm}$, at $37^{\circ} \mathrm{C}, 240 \mathrm{rpm}$, completely $30 \mathrm{~min}$ ( $2 \mathrm{~nm}$ every $5 \mathrm{~min}$ ). Lyophilisation was processed for $48 \mathrm{~h}$ at $-80^{\circ} \mathrm{C}$ and $0.1 \mathrm{mbar}$ (Labconco, USA). Test Samples: Artificial urine samples were prepared according to available protocols [19]. Urine samples obtained from healthy volunteers $(K)$ were collected at time intervals. Samples $P$ were obtained from patients-voluntary donors with a histologically confirmed diagnosis of prostatic carcinoma (PCa). All procedures were performed in accordance with ethical principles. Sarcosine content was analysed by the proposed method. All participants signed informed consent to use their biological sample (E01/2019). From all participants, the informed consent for the collection and analysis of clinical samples was obtained. Sample analysis was performed by the methodology developed in this article. Data treatment and descriptive statistics. The experimental work was carried out in three independent experiments. The analysis of each sample was carried out 5 times. The obtained data are presented as average values. From the proposed study no experimental subjects were excluded from the proposed experimental studies. All the obtained data were stored in the QINSLAB database (Czech Republic). If possible, data was processed and evaluated mathematically and statistically in the QINSLAB database. Photographs were processed by programme ColorTest, which assigns intensity to the individual pixels of the studied image in the color area. For the publication purpose, data were processed using Microsoft (USA).

\section{RESULTS AND DISCUSSION}

The development of a simple assay for sarcosine analysis requires modification of conventional procedures. Our design uses superparamagnetic irone oxide nanoparticles (SPION) modified by SOX and HRP enzymes [13] as shown in Figure 2A. For long-term use, SPION enzyme nanoparticles were lyophilized for $48 \mathrm{~h}$ at $-80^{\circ} \mathrm{C}$ and $0.1 \mathrm{mbar}$ pressure in glass vials. After successful lyophilization, a layer of modified nanoparticles was formed at the bottom of the vial. The nanoparticles thus prepared exhibited long-term stability of more than 3 months at room temperature (enzyme activity decrease by about $10 \%$ ). Lyophilized SPION / HRP / SOX were activated by addition of reaction solution (its composition was optimized in our previous work $[10,13])$ and then a studied urine sample was applied. The sensitivity of the method to sarcosine was good when using various artificial urines (LOD between 1 and $5 \mu \mathrm{M}$ ) [11], however, when the protocol was applied to a real urine sample, the sensitivity was affected and the LOD was around $20 \mu \mathrm{M}$. Therefore, we proceeded to search for a novel modification using the reaction of peroxide with 10-acetyl-3,7-dihydroxyphenoxazine to the color 7-hydroxy-3H-phenoxazine-3-one (Figure 1). Figure 2B shows a typical color reaction (Amplex Red, $0.5 \mathrm{mM})$ and sarcosine $(100 \mu \mathrm{M})$. The obtained intense pink color was in the visible area and there was clear fluorescence under the UV lamp. In other experimental works we observed the absorption spectrum of sarcosine $(20 \mu \mathrm{M})$, which was very reproducible and the signal intensity was $20-40 \%$ higher compared to the method using the reaction with 4-aminoantipyrine (Figure 2C). Figure 2D shows the temporal change in the signal of resorphine produced by the hydrolysis of sarcosine SOX $(20 \mu \mathrm{M})$. The analysis was performed at intervals every 5 minutes for a total measurement time of $60 \mathrm{~min}$. The resulting spectra show two absorption maxima, one around $530 \mathrm{~nm}$ and the other around $570 \mathrm{~nm}$. These changes will be related to the course of oxidation of 10-acetyl-3,7-dihydroxyphenoxazine to color 7-hydroxy-3H-phenoxazine-3-one [16]. For quantitative evaluation of sarcosine concentration, it is preferable to use a signal at $570 \mathrm{~nm}$. The main objective of the experimental work was to apply the proposed procedure to real urine samples. Therefore, experiments were carried out in various environments (phosphate buffer $\mathrm{pH} \mathrm{7,} \mathrm{artificial} \mathrm{urine} \mathrm{AU-N} \mathrm{and} \mathrm{real} \mathrm{urine).} \mathrm{We}$ found that limit of detection (LOD) in phosphate buffer was around $2 \mu \mathrm{M}$ (RSD $4.75 \%$ ), in AU-N, LOD was about $1 \mu \mathrm{M}$ and RSD was $5 \%$, in real urine LOD was about $6 \mu \mathrm{M}$ (RSD $10.87 \%$ ), when the number of repetitions was 5 .

Subsequently, we focused on a more detailed study of reaction behavior in real urine samples. Mixed urine was prepared for this purpose (collected during the day, then sterilized and filtered; conductivity $25 \mathrm{mS}, \mathrm{K} 26$ $\mathrm{mmol} / \mathrm{L}, \mathrm{Cl} 202 \mathrm{mmol} / \mathrm{L}, \mathrm{Na} 11 \mathrm{mmol} / \mathrm{L}, \mathrm{pH} 7.28$, density $1.0210 \mathrm{~g} \cdot \mathrm{cm}^{-3}$, creatinine $10.4 \mathrm{mmol} / \mathrm{L}$, ascorbic 
acid $3.97 \mu \mathrm{mol} / \mathrm{L}$, uric acid $4 \mathrm{mmol} / \mathrm{L}$, urea $290 \mathrm{mmol} / \mathrm{L}$, protein $7 \mathrm{mg} / \mathrm{L}$, redox $21.5 \mathrm{mV}$ ). We observed changes in sarcosine color reaction signals at different concentrations $(0-50 \mu \mathrm{M})$, RSD ranged from 9.79 to $18.51 \%$ and LOD was around 2 - $4 \mu \mathrm{M}$ sarcosine concentration. In other experiments we focused on monitoring the effect of Amplex Red concentration ( $0 ; 0.10 ; 0.20 ; 0.50 ; 1.00 \mathrm{mM})$. Typical absorption spectra showed that the maximum sarcosine response $(100 \mu \mathrm{M})$ was around $0.50 \mathrm{mM}$ at Amplex Red, and no increase in color resorphine signal was observed at higher Amplex Red concentrations above $0.50 \mathrm{mM}$. Lower concentrations of Amplex Red led to the formation of less colored resorphine and thus reduced sensitivity of the method. On the other hand, a color reaction was observed in real urine samples without sarcosine present at higher Amplex Red concentrations applied (over $5 \%$ of test samples). Decreasing the Amplex Red concentration resulted in a false positive below $5 \%$. Potential interfering substances, especially albumin and creatinine, were studied in other experiments. We found that increased concentrations of these compounds in the real urine sample increase RSD by about $5-10 \%$. In addition, the effects of uric acid, urea, increased ionic concentration ( $\mathrm{Na}$, $\mathrm{K}, \mathrm{Cl}$ ) and total protein on signals were studied. Here again, there was no significant effect on the course of the reaction. Only changes in the range of $5-10 \%$ RSD were observed. The photoactivation of the test under irradiation with a conventional fluorescent lamp was found to be the most serious interfering effect. In this case, a color reaction developed in the control variant (no sarcosine) within $30 \mathrm{~min}$. This negative effect was completely eliminated by preventing the access of lighting. The reproducibility of such a test at the applied sarcosine concentration $(100 \mu \mathrm{M})$ was very good and recovery ranged between $95-105 \%$.

(A)

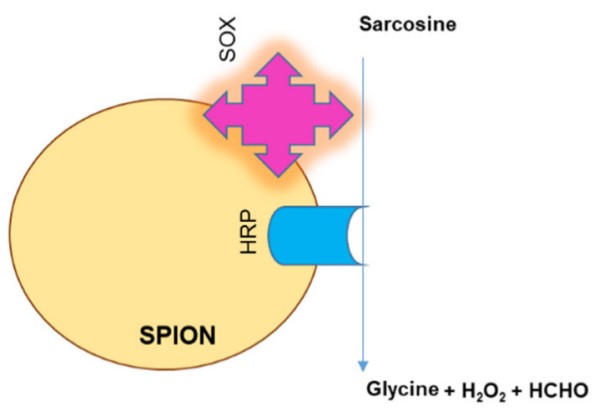

(B)

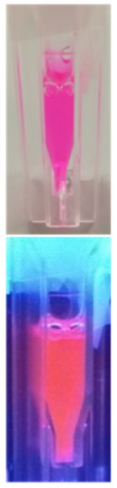

(C)

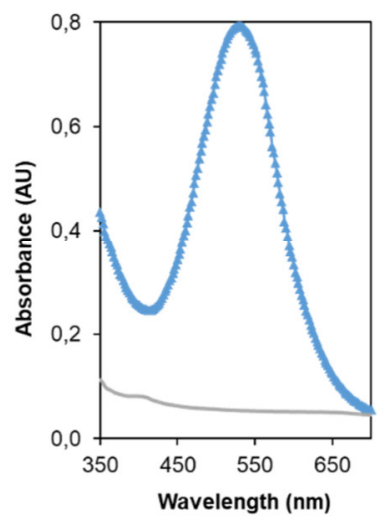

(D)

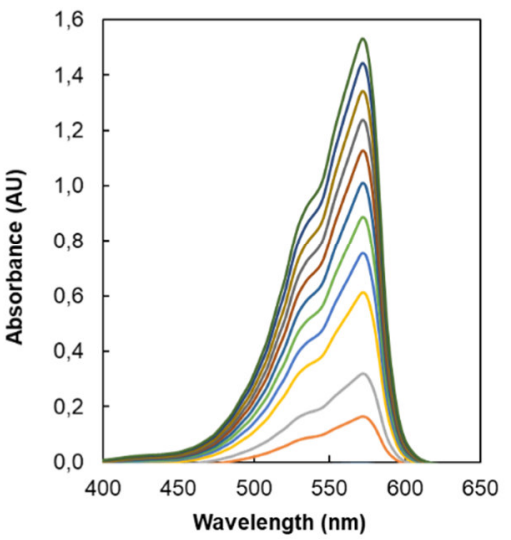

Figure 2. Probable scheme of SPION modified by SOX and HRP. Sarcosine is hydrolyzed to form glycine, formaldehyde and hydrogen peroxide. Hydrogen peroxide in the presence of 10-acetyl-3,7-

dihydroxyphenoxazine reacts to the colored 7-hydroxy-3H-phenoxazine-3-one (A). Typical color reaction of sarcosine $(100 \mu \mathrm{M})$; intense pink color in the visible area and under the UV lamp bright fluorescence (B). The typical absorption spectrum of sarcosine $(20 \mu \mathrm{M})$ after $30 \mathrm{~min}$ interaction at $25^{\circ} \mathrm{C}$, the gray line is a sarcosine-free reaction $(\mathrm{C})$. Time change of signal of resorphine produced by sarcosine hydrolysis $(20 \mu \mathrm{M})$, measurement intervals every 5 minutes for a total measurement time of 60 min (D).

We tested various real urine samples $(n=10)$ using the Amplex Red method for visual evaluation of the color reaction (Figure 3). We found that we were able to recognize sarcosine at concentration range from 2.5 to 5 $\mu \mathrm{M}$. The specificity and sensitivity of the test was then evaluated. In the subsequent evaluation of the ROC curves we found a sensitivity of about 0.8 and a specificity of about 0.9 , but some samples showed a specificity of only 0.2 . The average ROC curve obtained had an AUC of 0.727 , which is justified and good according to the classification ratings used. The obtained results are completely piloted and the proposed methodology will be tested in more detail on a larger sample set. 
(A)

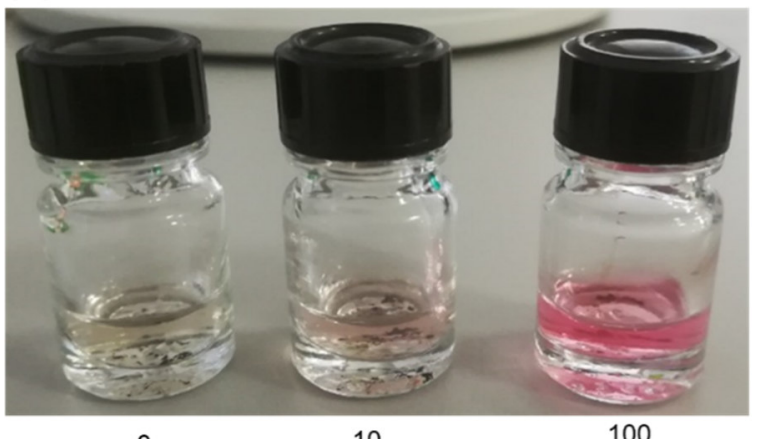

0

10

100

Sarcosine concentration $(\mu \mathrm{M})$

(B)

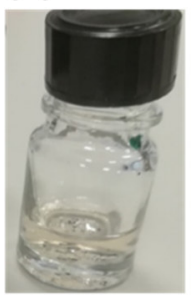

0.00

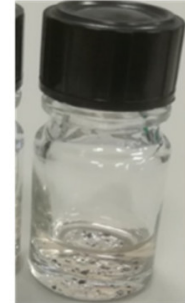

1.25

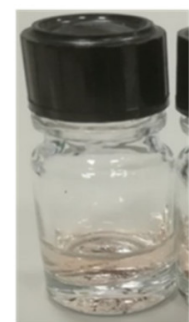

2.50

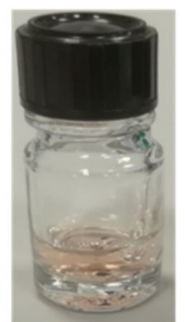

5.00

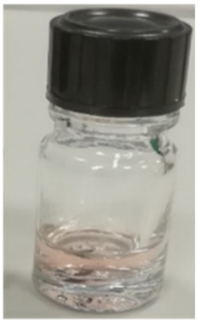

10.00

Sarcosine concentration $(\mu \mathrm{M})$

Figure 3 Visual assessment of the color reaction of the sarcosinuria test in a real urine sample. Typical reaction when evaluating higher urine concentrations $(A)$ and lower urine concentrations $(B)$. Other experimental conditions are given in Material and Methods section.

\section{CONCLUSION}

The high sensitivity method for detecting the amino acid sarcosine using Amplex Red has been optimized. The proposed method increased sensitivity in a real urine sample with an LOD of around $2 \mu \mathrm{M}$ (RSD $10 \%$ ). In addition, the proposed procedure is also suitable for visual assessment when sarcosine concentrations around $2.5 \mu \mathrm{M}$ could be detected. When evaluating the ROC curves, the area under the AUC curve was 0.727 .

\section{ACKNOWLEDGEMENTS}

The work was supported by the SARKOTEST 165/2015 project and the European Technology Platform for Nanomedicine.

\section{REFERENCES}

[1] TRINDER, P. Determination of blood glucose using 4-amino phenazone as oxygen acceptor. J. Clin. Pathol., 1969, vol. 22, no. 2, pp.

[2] ALTWAIJRY, N., SOMANI, S., DUFES, C. Targeted nonviral gene therapy in prostate cancer. Int. J. Nanomed., 2018, vol. 13, no. pp. 5753-5767.

[3] SAWYERS, C. L. The cancer biomarker problem. Nature, 2008, vol. 452, no. 7187, pp. 548-552.

[4] LUCARELLI, G., LOIZZO, D., FERRO, M., RUTIGLIANO, M., VARTOLOMEI, M. D., CANTIELLO, F., BUONERBA, C., DI LORENZO, G., TERRACCIANO, D., DE COBELLI, O., BETTOCCHI, C., DITONNO, P., BATTAGLIA, M. Metabolomic profiling for the identification of novel diagnostic markers and therapeutic targets in prostate cancer: an update. Expert Review of Molecular Diagnostics, 2019, vol. 19, no. 5, pp. 377-387. 
[5] SREEKUMAR, A., POISSON, L. M., RAJENDIRAN, T. M., KHAN, A. P., CAO, Q., YU, J. D., LAXMAN, B., MEHRA, R., LONIGRO, R. J., LI, Y., NYATI, M. K., AHSAN, A., KALYANA-SUNDARAM, S., HAN, B., CAO, X. H., BYUN, J., OMENN, G. S., GHOSH, D., PENNATHUR, S., ALEXANDER, D. C., BERGER, A., SHUSTER, J. R., WEI, J. T., VARAMBALLY, S., BEECHER, C., CHINNAIYAN, A. M. Metabolomic profiles delineate potential role for sarcosine in prostate cancer progression. Nature, 2009, vol. 457, no. 7231, pp. 910-914.

[6] PUNDIR, C. S., DESWAL, R., KUMAR, P. Quantitative analysis of sarcosine with special emphasis on biosensors: a review. Biomarkers, 2019, vol. 24, no. 5, pp. 415-422.

[7] GARCIA-PERDOMO, H. A., VALLEJO, F. G., SANCHEZ, A. Metabolic Profiling Based on Nuclear Magnetic Resonance Spectroscopy and Mass Spectrometry as a Tool for Clinical Application. Urological Science, 2019, vol. 30, no. 4, pp. 144-150.

[8] YAMKAMON, V., PHAKDEE, B., YAINOY, S., SUKSRICHAWALIT, T., TATANANDANA, T., SANGKUM, P., EIAMPHUNGPORN, W. Development of Sarcosine Quantification in Urine Based on Enzyme-Coupled Colorimetric Method in or Prostate Cancer Diagnosis. Excli Journal, 2018, vol. 17, no. pp. 467-478.

[9] CERNEI, N., ZITKA, O., RYVOLOVA, M., ADAM, V., MASARIK, M., HUBALEK, J., KIZEK, R. Spectrometric and Electrochemical Analysis of Sarcosine as a Potential Prostate Carcinoma Marker. Int. J. Electrochem. Sci., 2012, vol. 7, no. 5, pp. 4286-4301.

[10] UHLÍŘOVÁ, D., DOČEKALOVÁ, M., STAŇKOVÁ, M., RU゚ŽIČKA, J., KIZEK, R. Reakční směs pro kvantitativní stanovení sarkosinu ve vzorku lidské moči, séra nebo plazmy. Patentový spis, 2018, vol. CZ 307555 B6, no. pp.

[11] UHLíŘRVÁ, D., DOČEKALOVÁ, M., STAŇKOVÁ, M., RU゚ŽIČKA, J., KIZEK, R. Reakční směs pro kvantitativní stanovení sarkosinu ve vzorku lidské moči, séra nebo plazmy. Užitný vzor, 2017, vol. CZ 30896 U1, no. pp.

[12] LAN, J. M., XU, W. M., WAN, Q. P., ZHANG, X., LIN, J., CHEN, J. H., CHEN, J. Z. Colorimetric determination of sarcosine in urine samples of prostatic carcinoma by mimic enzyme palladium nanoparticles. Analytica Chimica Acta, 2014, vol. 825, no. pp. 63-68.

[13] UHLIROVA, D., STANKOVA, M., DOCEKALOVA, M., HOSNEDLOVA, B., KEPINSKA, M., RUTTKAY-NEDECKY, B., RUZICKA, J., FERNANDEZ, C., MILNEROWICZ, H., KIZEK, R. A Rapid Method for the Detection of Sarcosine Using SPIONs/Au/CS/SOX/NPs for Prostate Cancer Sensing. Int. J. Mol. Sci., 2018, vol. 19, no. 12, pp. 29.

[14] XUE, Z. H., YIN, B., WANG, H., LI, M. Q., RAO, H. H., LIU, X. H., ZHOUA, X. B., LU, X. Q. An organic indicator functionalized graphene oxide nanocomposite-based colorimetric assay for the detection of sarcosine. Nanoscale, 2016, vol. 8, no. 10 , pp. 5488-5496.

[15] TOTHOVA, Z., DOCEKALOVA, M., STANKOVA, M., UHLIROVA, D., PANTUCKOVA, P., KIZEK, R. Elektrochemická analýza vlivu zinku na sarkosin oxidázu. Czech Chem. Soc. Symp. Ser., 2018, vol., no. pp. 377.

[16] WANG, N. N., MILLER, C. J., WANG, P., WAITE, T. D. Quantitative determination of trace hydrogen peroxide in the presence of sulfide using the Amplex Red/horseradish peroxidase assay. Analytica Chimica Acta, 2017, vol. 963, no. pp. 61-67.

[17] CHAKRABORTY, S., HILL, A. L., SHIRSEKAR, G., AFZAL, A. J., WANG, G. L., MACKEY, D., BONELLO, P. Quantification of hydrogen peroxide in plant tissues using Amplex Red. Methods, 2016, vol. 109, no. pp. 105-113.

[18] UHLIROVA, D., STANKOVA, M., DOCEKALOVA, M., HOSNEDLOVA, B., KEPINSKA, M., RUTTKAY-NEDECKY, B., RUZICKA, J., FERNANDEZ, C., MILNEROWICZ, H., KIZEK, R. A Rapid Method for the Detection of Sarcosine Using SPIONs/Au/CS/SOX/NPs for Prostate Cancer Sensing. Int. J. Mol. Sci., 2018, vol. 19, no. 12, pp. 29.

[19] SHMAEFSKY, B. R. Artificial urine for laboratory testing Amer. Biol. Teacher, 1990, vol. 52, no. 3, pp. $170-172$. 